\title{
内リンパ霅局所免疫動物におけるフリーラジカルの関与について
}

\author{
日本医科大学耳鼻咽喉科学教室（主任：八木聰明教授） \\ 木下俊 芝, 富山俊一 \\ FREE RADICALS IN INNER EAR IMMUNE RESPONSES; \\ IMMUNOHISTOCHEMICAI. STUDY OF MYELOPEROXIDASE
}

TOSHIYUKI KINOSHITA, M.D. and SHUN-ICHI TOMIYAMA, M.D.

Department of Otolaryngology, Nippon Medical School, Tokyo

\begin{abstract}
Previously, we reported that immune reactions in the endolymphatic sac of guinea pigs caused spontaneous nystagmus, a suppressed caloric response, and fluctuating hearing loss. In order to evaluate immune injury to the sensory organs of the inner ear, we conducted an immunohistochemical investigation of the distribution and time course of myeloperoxidase (MPO) following immune reaction in the endolymphatic sac. MPO staining can be seen in the endolymphatic sac, outer hair cells, stria vascularis and lateral canal (ampulla), from several hours to 3 weeks after a secondary $\mathrm{KLH}$ challenge, and its time course parallels the time course of neutrophil infiltration of the endolymphatic sac. This result indicates that free radicals in the MPO- $\mathrm{H}_{2} \mathrm{O}_{2}-\mathrm{Cl}$ system are responsible for the tissue damage and dysfunction resulting from inner ear immune reactions.
\end{abstract}

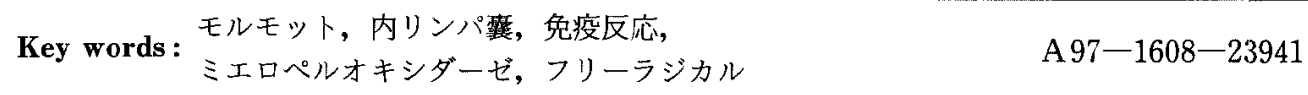

I はじめに

メニエール病の病理組織学的特徵が内リンパ水腫に あることは山川 ${ }^{11}$, Hallpike ${ }^{2)}$ ら以来, 種々の報告があ る.しかし，内リンパ水腫自体の発生原因はいまだに 明らかにされていない。

最近, 内リンパ襄が内耳において唯一免疫応答能力 を備えた部位であることが明らかとなってき

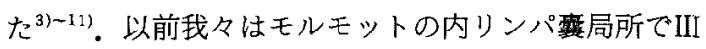
型免疫反応を惹起させた結果, 組織学的変化として内 リンパ襄の炎症細胞浸潤と内リンパ水腫 ${ }^{12) 13)}$, 内耳機 能変化として自発眼振出現, 温度眼振抑制 ${ }^{14)}$ および変 動する感音難聴 ${ }^{15) 16)}$ が生ずることを示した。またこ れがヒトのメニエール病に極めて類似した病態像であ ることから，本法によって作製した動物がメニエール 病の実験動物モデルとして有用であることを報告し た.

内リンパ嚢におけるIII型免疫反応が主体である本動
物モデルでは，その組織傷害，機能障害の原因として 免疫反応を介してのフリーラジカル, 補体, サイトカ インなど種々の因子が関与している可能性が考えられ る. 同様な好中球浸潤が生じる慢性系球体腎炎の動物 モデルやヒトの慢性関節リウマチにおいて，その組織 傷害におけるフリーラジカルの関与が報告されてお り，ことに好中球から放出されるミエロペルオキシダ 一ゼ (MPO) と, 組織傷害, 機能障害の関係が報告さ れている ${ }^{17) 18119 !}$.また, 慢性関節リウマチなどではフリ ーラジカルを制御することによって治療に結び付けよ うとする試みもなされ始めている。

今回, 内リンパ藵局所免疫動物に扔ける組織学的傷 害抢よび機能的障害の機序の一つとしてのフリーラジ カルの関与を調べる目的で, 好中球を介してのフリー ラジカル産生において重要な役割を果たす MPOの局 在えよび経時的な推移について免疫組織化学的検討を 行った. 結果として, 内リンパ壤局所に浸潤した好中 
球内のアズール顆粒内のみでなく，脱顆粒された MPO が蝸牛や前庭に到達し沈着していることが明ら かとなったので，その意義について考察を加えながら その局在および経時的な分布の変化について報告す る。

\section{II 方 法}

KLH 抗原 (Keyhole Lympet hemocyanin, Calbiochemist, La Jolla, CA, Lot730052) による全身感作, および内りンパ舼局所免疫の方法は既に報告した ${ }^{12) 13}$ ので簡略に述べる、ハートレー系モルモット $(350 \mathrm{~g}-$ $400 \mathrm{~g}$ 雌, 埼玉実験動物) に, KLH $500 \mu \mathrm{g}$ を complete Freund's adjuvant とともに全身皮下感作し，さらに KLH incomplete freund's adjuvant とともに2回, 2 週毎に追加免疫として皮下投与した.内リンパ舼局 所感作は pentobarbital sodium, fentanyl citrate によ る麻酔下に後頭蓋硬膜内経由で行い, KLH $100 \mu \mathrm{g} / 5 \mu \mathrm{l}$ を右内リンパ襄内に注入した。感作後 $2,5,10$ 時間, 1，2，3，7，14，21日を経過した時点でそれぞれ 5 匹ずつ屠殺し, 酶酸加 $10 \%$ ホルマリン生食による心 灌流固定ののち組織を採取, 同固定液に一晚固定し, EDTA 脱灰, パラフィン包埋, 切片薄切, 脱パラフィ ンの後, 免疫組織染色を行った。一次抗体としてウサ ギ抗ヒト MPO ポリクロナール抗体(DAKO 社製)，免 疫染色には LSAB キット (DAKO) を用い, 内因性ペ ルオキシダーゼを $3 \% \mathrm{H}_{2} \mathrm{O}_{2}$ で阻止し，DABで発色さ せ, Glycerol-gel(DAKO) で封入した。一次抗体濃度 は900倍とした。ポジティブコントロールとしてモルモ ットの脾臓を用い，また，ネガティブコントロールと しては一次抗体の代わりにウサギ正常血清を用いた。 また，対照実験として，全身感作を行わずに燐酸緩衝 生理食塩水 Ph 6.4 (PBS) を内リンパ垔に注人した動 物を作製し，内リンパ賈への手術操作のみによる影響 についての対照とした。 また，正常内耳についても検 討した.

染色後組織を光顕で観察し，組織の染色の度合いを 肉眼的にネガティブコントロールと同等を一，ポジテ イブコントロールのアズール顆粒と同等を+十+とし $\tau,-, \pm,+,++,+++\infty 5$ 段階に分類した.

内リンパ襄局所への細胞浸潤の程度についても経時 的に検討した. 光顕下 400 倍 1 視野あたり炎症細胞10個 までを grade I，11-100個を grade II，101個以上を grade III, 無数に細胞浸潤を認めるものを grade IV とした ${ }^{13)}$.
III 結 $\quad$ 果
1. ポジティブコントロール (脾臓)
モルモット脾臓組織では, 好中球のアズール顆粒の みに褐色に染まる明瞭な MPO 染色を認めた（図 1 ）。

2. ネガティブコントロール

モルモット脾蔵について，ウサギ抗ヒト MPO 抗体 の代わりにウサギ正常血清を用いて脾缄組織を反応さ せたが，特異的な区応は認めなかった（図 2)。

3. 正常内耳

正常内耳では, 内リンパ震, 蝸牛, 半規管とも MPO 染色は認めなかった。

\section{4. 対照耳 (PBS 注入群)}

内リンパ露上皮にはごくわずかな MPO 染色を認め たが, 前庭, およで蝸牛組織での MPO 染色は認めなか った (図 3 ).

5. 実験耳

内リンパ虂, 前庭, 䗁牛各部位の MPO 染色性の経時 的推移を図 $4(\mathrm{a}-\mathrm{e})$ に示した。また，内リンパ隼 への炎症細胞浸潤の程度の経時的推移を図 $4 \mathrm{f}$ に示し た.

\section{1）内リンパ震}

上皮，内リンパ蹍周囲組織に二次感作 5 時間後から MPO の染色を認め，1-2日をピークとして次第に 染色性が減弱し，21日目にはほとんど染色を認めなく なった(図 $4 \mathrm{a} ， 5 ， 6$ ). 内リンパ露腔内, 浮遊細胞

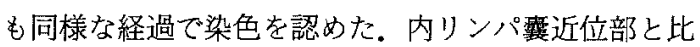
して遠位部，中間部にMPO 染色が強かった。

内リンパ霬局所への好中球浸潤は二次感作 2 時間か ら 5 時間後より認められ，1 日目で grade IV と著明 な浸潤を示した(図 $4 \mathrm{f}$ ). 図 $4 \mathrm{a}$ - e , $4 \mathrm{f}$ の比較か ら明らかなように，今回の実験での内リンパ慗の $\mathrm{MPO}$ 染色性と内リンパ垔局所の好中球浸潤の経時的 推移はほほ一致していた。また，14日，21日目では， 浸潤している細胞はほとんどがリンパ球におきかわっ ていた.

2）螖牛

蝸牛局所には好中球の浸潤を認めなかった。らせん 器では, 外有毛細胞に明瞭なMPOによる染色が認め られた。他に，クラウディウス練胞，へンゼン細胞に ついても二次感作 5 時間目から染色を認めはじめ, 1 一2 日目をピークとして次第に減弱し，21日目では極 めて軽微となった（図 $4 \mathrm{~b} ， 7 ， 8$ ). 外りンパ腔領域 にはMPO 染色は認めなかった。

血管条では，辺縁細胞に 5 時間目から MPO 染色を 

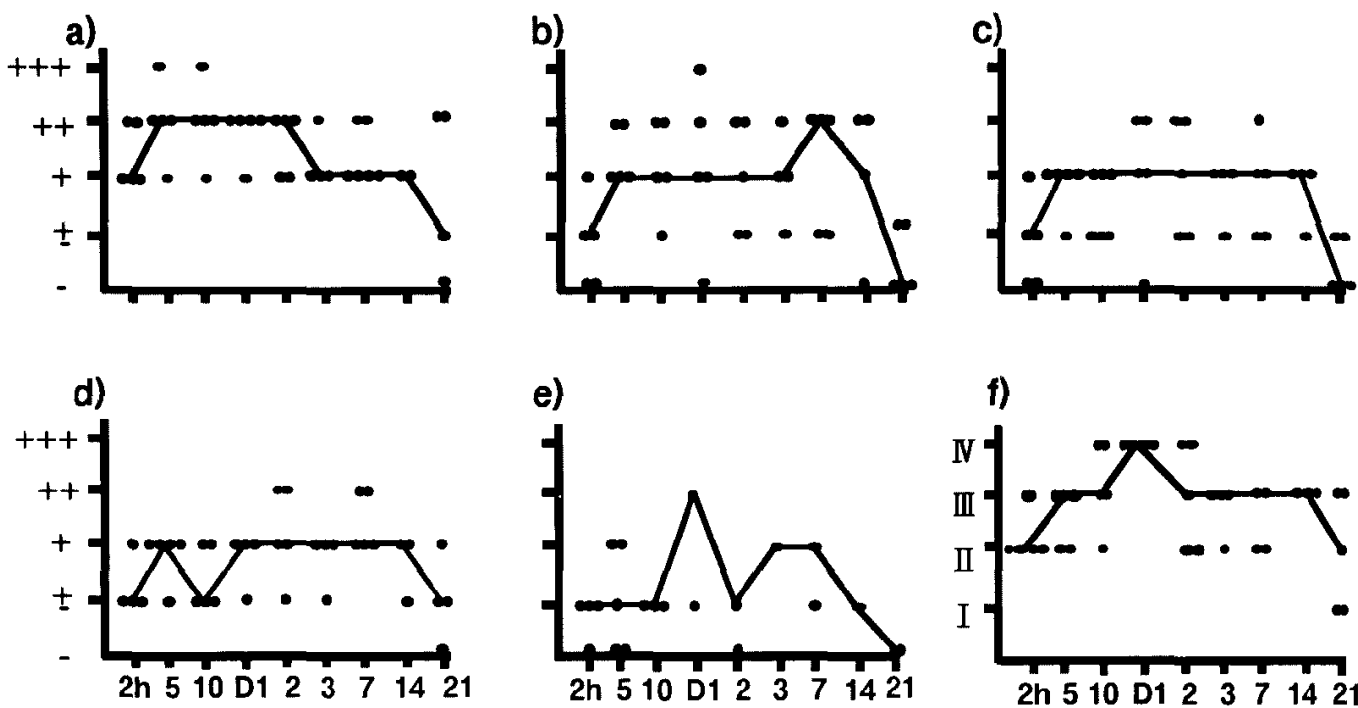

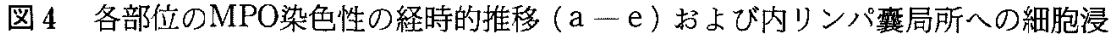
潤の程度 (f f ) を示した．横軸が内リンパ霊二次感作から屠殺までの期間，縦

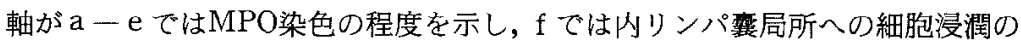
程度を示す.点 1 個が動物 1 匹を示し，実線は中央値を結んだもの.a：内リン

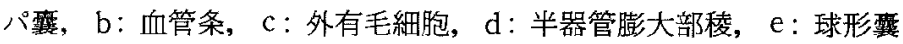

認め，1-2 日目をピークとして21日目にかけて染色 性が減弱した (図 4 C).

らせん靯帯では 5 時間目から MPO 染色を特に血管 周囲に認め，1-2 日目をピークとして21日目にかけ て減弱した。

3）前庭

半規管，卵形露，球形藂には好中球の浸潤を認めな かった。

半規管では，外側半規管膨大部のクプラ，クプラ下 空, 感覚上皮細胞, 膨大部棱で二次感作 5 時間目から MPO 染色を認め，1-2 日をピークとして21日目に は消退した（図 $4 \mathrm{~d} ， 9 ， 10)$.

球形踖でも局所好中球浸潤はないにもかかわらず, 感賞上皮細胞に 5 時間目から染色を認めはじめ，12 日目をピークとして次第に隇弱した（図 4 e). 球形 褧空内には染色は認めなかった。

\section{IV 考 察}

近年, 種々の疾患にフリーラジカルや活性酸素が関 与していることを示す報告が散見される。活性酸素と は，狭義には $\mathrm{H}_{2} \mathrm{O}_{2}, \mathrm{O}_{2}{ }^{-}$，・ $\mathrm{OH},{ }^{1} \mathrm{O}_{2}$ の 4 種類であ る。こ机ら㹥分子内に不対電子を持ち, この不対電子
が隣接する分子に移動し，その分子膜やDNAの過酸 化を生じさせることにより組織傷害を引き起こすもの である.フリーラジカルとは上記の 4 種類のみでなく， 不対電子を持ち，近接分子への過酸化能力を持つすべ ての分子をいう。

MPO は，好中球アズール顆粒内に存在する分子量 約 11,8000 人么蛋白である ${ }^{20)}$. MPO は，炎症刺激によ り好中球が活性化されると脱顆粒によって好中球外に 放出され，好中球膜で生じた $\mathrm{O}_{2}{ }^{-}$により生じる $\mathrm{H}_{2} \mathrm{O}_{2}$ と，体液中に豊富に存在する塩素イオンを基質として 次亜塩索酸 $(\mathrm{HOCl})$ を生じる ${ }^{17) 18199}$. $\mathrm{HOCl}$ は, それ 自体がラジカルとして働いたり，最も強い酸素種であ る・OH を生じたりする。これらが生体膜のリン脂質 二重膜構造を過酸化し，組織傷害や機能障害を生じき せるとされている。この好中球を介してのフリーラジ カルの反応系, Johnson ら tem と呼んでいる ${ }^{1718) 199}$. 種々の炎症のモデルにおい て，局所に浸潤した好中球によってこのような機序の 組織傷害が生じることが確かめられている，今回用い た動物モデルでも，III型免疫反応によって内リンパ襄 局所に著明な好中球浸潤が確認されていること ${ }^{13)}$ ら, 好中球から脱顆粒された MPO を介した $\mathrm{MPO}-\mathrm{H}_{2}$ 


\section{木下論文付図 (1)}

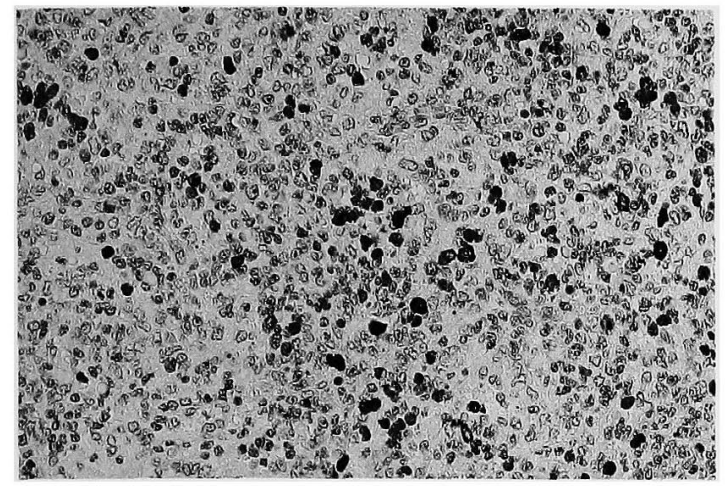

図 1 ポジティブコントロール：モルモット脾臓 組織. 好中球アズール顆粒の明瞭な MPO 染色を認める。

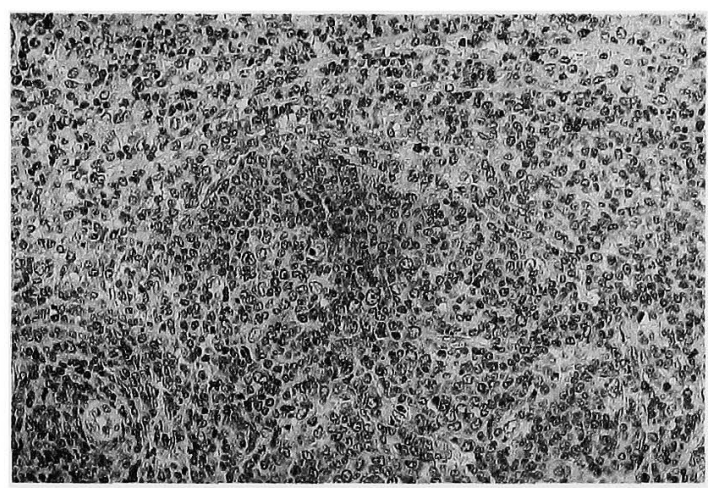

図 2 ネガティブコントロール：モルモット脾臓. ウサギ正常血清では染色を認めなかった。

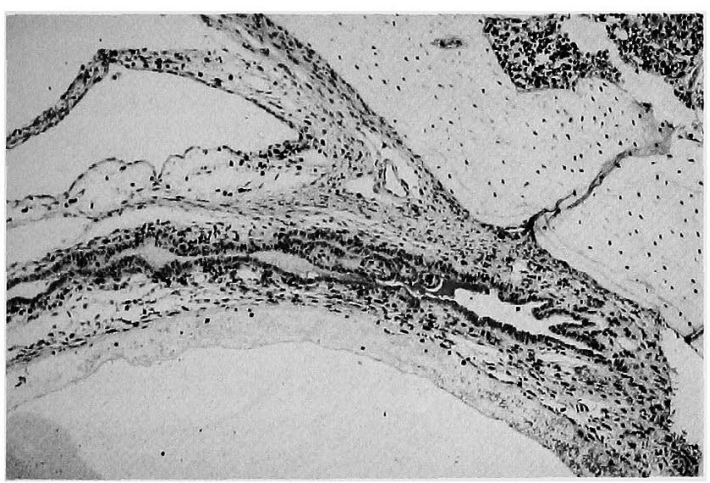

図3 対照実験耳 (PBS 注入群)：内リンパ露上 皮にのみごくわずかな染色を認めたが，好 中球浸潤はみられなかった。

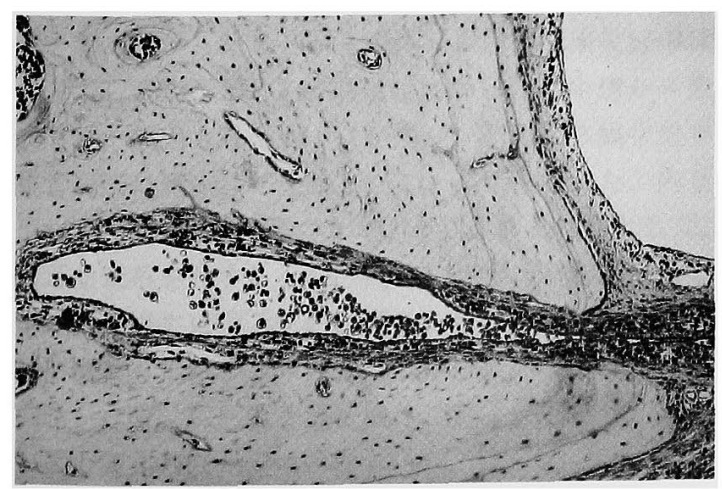

図 6 内リンパ霊（二次感作21日目：内リンパ 腔内の細胞は主にリンパ球に拉きかって おり，MPO染色性も低下している。

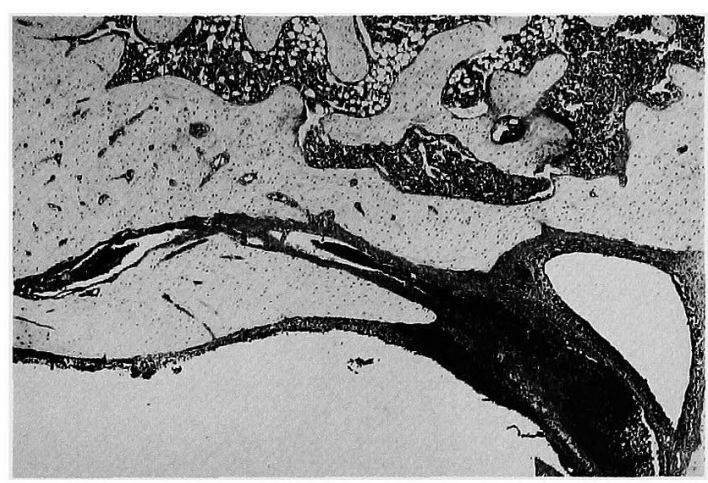

図 5 内リンパ踾 (二次感作 1 日目)：内リンパ腔 に著明な奵中球浸潤を認めた。MPO染色 性 +++ . 


\section{木 下 論 文 付 図 (2)}

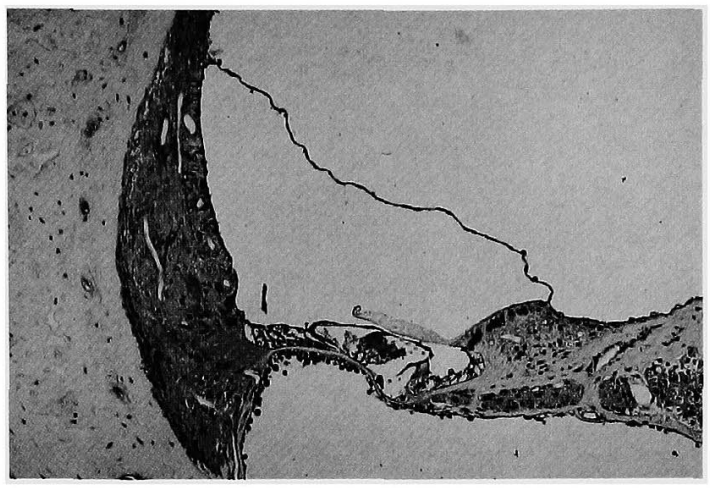

図7 蝸牛 (二次感作 1日目)：血管条辺縁細胞, 外有毛細胞, ヘンゼン細胞, クラウディウ 又細胞，らせん鞋帯に染色を認めた。

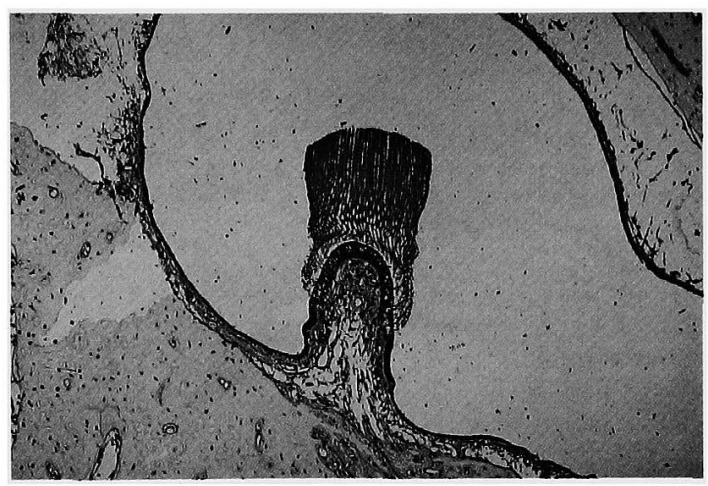

図 9 外側半規管 (二次感作 2 日目)：クプラ, ク プラ下腔, 感賞上皮細胞, 膨大部稜に染色 を認めた。

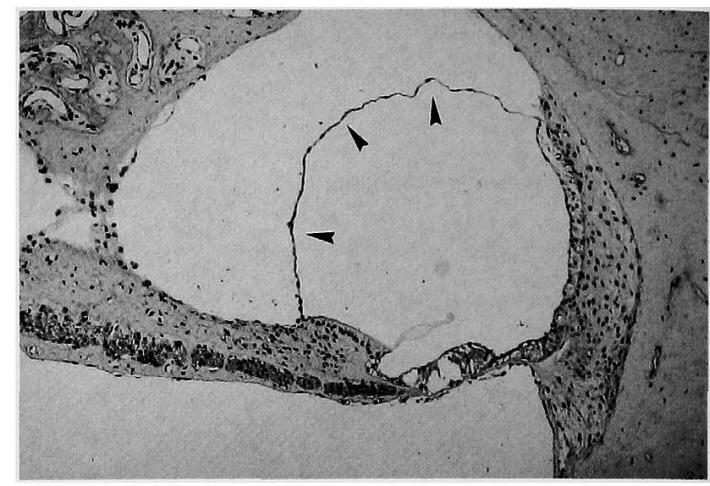

図 8 蝸牛 (二次感作 21日目)：MPO染色性は ほとんど認めない，知印のごとく内リンパ 水腫を認めた。

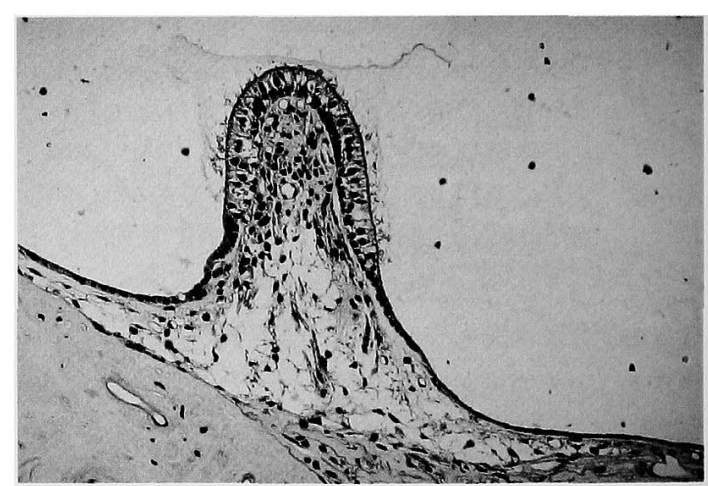

図 10 外側半規管 (二次感作 21日目)：MPO染 色性をほとんど認めない，感賞上皮の空 胞化を認めた。 
$\mathrm{O}_{2}$-Cl system によりフリーラジカルの反応が生じ, 組 織傷害, 機能障害が引き起こされているであろうこと は容易に想像される。

モルモット脾葴を用いたポジティブコントロールで は, 好中球アズール顆粒に一致した特異的 MPO 染色 を認め，ウサギ抗ヒトMPOポリクロナール抗体はモ ルモット MPOに対しても交叉性を持つことが示され た. 対照群 (PBS 注入群) では, 内リンパ軎にのみご くわずかな染色を㑇めたが，これはPBSを内リンパ 襄に注入した手術操作自体でごく軽微な組織損傷や炎 症が生じたものと考えられる。しかし，螖牛，前庭に はMPOは到達しておらず，この対照群においては聴 力障害, 平衡障害は生じないであううことが推測され る.こ扎恃，以前に我々が報告した，PBS 注入群では 温度眼振反応, 聴力の低下は来さないという結果と一 致尔主年15)16?.

実験耳 (二次感作群) では, KLH 内リンパ囊注入後 1-2 日をピークとして, 蝸牛外有毛細胞, クラウデ イウス細胞, ヘンゼン細胞, 血管条の辺緑細胞, らせ ん勒带, 外側半規管膨大部の感覚上皮細胞, クプラ, クプラ下空, 膨大部稜, 球形熼にMPOの染色を認めて いる，以前我々法，二次感作後 1 日以降の内耳組織を 検討し，1日目で内リンパ襄局所の著明な好中球浸潤 を認め始め, 約 1 週間で好中球が消退しリンパ球にお きかわることを報告した ${ }^{13)}$.今回の実験では,さらに詳 細に感作後 2 時間, 5 時間, 10 時間後での内リンパ襄 細胞浸潤の程度を検討した結果，二次感作後 5 時間で 明らかな内りンパ豪への多数の多核白血球の浸潤を認 めた。今回得られた内リンバ囊での染色性のピークは, この内リンパ䧶への好中球浸潤の経過とほほ一致して いた.また，螖牛や球形㐮，半規管局所には好中球浸 潤を認めなかったことから，内リンパ霬局所に好中球 が遊走した後，MPO が脱顆粒によって好中球加放 出され，放出された MPOが内リンパ雍から螖牛や半 規管局所に到達して沈着したことが示唆された.内リ ンパ蘘から蝸牛, 前庭に MPO が到達する経路として, 内耳血管系を介するもの, 内リンパ管, 球形噇を経て 半規管や蝸牛に至るものが考えられる.今回の実験で

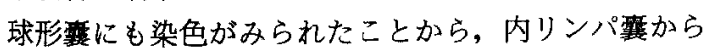
内リンパ管, 球形檋を経て蝸牛, 前庭に到達する経路 が最も考えられた。

螖牛, 前庭に分布した MPOがどのように消退して くか，という点が解明されれば，MPO 消退を早める ような操作を行えばメニエール病の治療に結びつくの
で重要であるが，今回の実験ではこれに関しての情報 は得られなかった。

Johnson らは，陽性荷電をもつ分子である MPOは 陰性荷電をもつ部位に沈着しやすく, 督葴に扔いても 陰性荷電をもった系球体基底膜にMPO が沈着して系 球体腎炎を生じると報告している(7)18).また, Tomoda

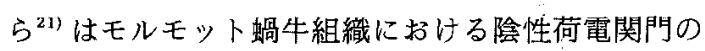
存在を竍告しており，陽性電荷をもった MPOが, 陰性 荷電をもった血管条などに沈着しやすいであろうこと が推測される.

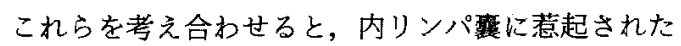
二次免疫反応によって好中球が内リンパ震に遊走浸潤 し, その好中球から放出された MPO が血管条, 外有毛 細胞, 外側半規管膨大部などに沈着し, MPO- $\mathrm{H}_{2} \mathrm{O}_{2}-\mathrm{Cl}$ systemによるフリーラジカルの反応が引き起こされ, 組織傷害, 機能障害を生じたと推測された。

今後, ヒトのメ二エール病でもフリーラジカルの反 応を制衙することで，発作を制御し得る可能性が示さ れた。

\section{$\mathrm{V}$ 結 語}

1.内リンパ靁免疫動物に䄧けるミエロペルオキシ ダーゼの局在を免疫組織学的に検討した.

2.内リンパ褒, 外有毛細胞, 血管条, らせん䓪带 などにMPOによる染色を認めた。

3.これらの $\mathrm{MPO}$ 染色のピークは，好中球浸潤の ピータとほほ一致していた。

4.内リンパ霊に遊走した好中球から $\mathrm{MPO}$ が放出 され, 蜦牛, 半規管組織に沈着することによって, MPO $-\mathrm{H}_{2} \mathrm{O}_{2}-\mathrm{Cl}$ system を介してフリーラジカルの反応が 起こり, 組織傷害, 機能障害が生じることが推測され た.

5. ヒトのメニエール病でも, フリーラジカルの反 応を制御することて、発作を制御し得る可能性が示さ れた。

\section{文献}

1) 山川強四郎：メニエール氏病 $习$ 呈セシ患者ノ聴器、日 耳鼻 $44: 2310-2312,1938$.

2) Hallpike CS, Cairns $\mathrm{H}$ : Observations on the pathology of Meniere's syndrome. J Laryngol 53:626655, 1938.

3) Guild SR: The circulation of the endolymph. Am J Anat 39: 57-81, 1927. 
4) Lundquist PG, Kimura RS, Wersall J: Ultrastructual organization of the epithelial lining in the endolymphatic duct and sac in the guinea pig. Acta Otolaryngol (Stockh) $57: 65-80,1964$.

5) Lim D, Silver P: The endolymphatic duct system. A light and electron microscopic investigation. In Barany Society Meeting, Los Angeles, CA, 1974, J Plec ed, p 390.

6) Rask-Andersen $\mathrm{H}$, Stahle J : Immunodefense of the inner ear? Lymphocytemacrophage interaction in the endolymphatic sac. Acta Otolaryngol (Stockh) 89: 283-294, 1980.

7) Arnold W, Altermatt HJ, Grebbers JO : Demonstration of immunoglobulin ( $\operatorname{Sg} A, \operatorname{IgG}$ ) in the human endolymphatic sac. Laryngol Rhinol Otol 63:464 $-467,1984$.

8) Tomiyama S, Harris JP: The endolymphatic sac. its importance of inner ear immune response. Laryngoscope 96 : 685-694, 1986.

9) Wackym PA, Friberg U, Linthicum FH et al: Human endolymphatic sac: Morphorogic evidence of immunologic function. Ann Otol Rhinol Laryngol 96:276-81, 1987.

10) Takahashi $M$, Harris JP: Anatomic distribution and localization of immunocompetent cells in normal mouse endolymphatic sac. Acta Otolaryngol (stockh) $106: 409-416,1988$.

11) Takahashi M, Harris JP: Analysis of immunocompetent cells following inner ear immunostimulation. Laryngoscope 98: 1133-1138, 1988.

12) Tomiyama $S$, Harris JP: The immunofunction of the endolymphatic sac in the inner ear immune response and endolymphatic hydrops following endolymphatic sac immune response. Otol Jpn 1 suppl (1) : 31-39, 1989.

13）富山俊一, 野中学, 八木聰明, 後藤祐一, 池園 哲朗: 内リンパ栾局所免疫反応による急性内リンパ水
腫 I：短期観察。日耳䔬 $94: 333-342,1991$.

14）野中 学, 富山俊一：内リンパ表局所免疫モルモット の前庭機能障害について，日耳鼻 $94 ： 1748-1755$, 1991 .

15）後藤袚一，富山俊一：内リンパ襄局所免疫反応による 内耳障害。日耳鼻 95：963-968，1992。

16）池園暂朗, 富山俊一：内リンパ蘘局所免疫動物の蛤電 図. 日耳鼻 $95: 809-816,1992$.

17) Johnson RJ, Couser WG, Klebanoff SJ et al : New mechanism for glomerular injury: Myeloperoxidase -hydrogenperoxide-halide system. J Clin Invest 79: 1379-1387, 1987.

18) Johnson RJ, Klebanoff SJ et al : Participation of the myeloperoxidase- $\mathrm{H}_{2} \mathrm{O}_{2}$-halide system in immune complex nephritis. Kidney int 32: 342-349, 1987.

19) Johnson RJ, Guggenheim SJ, Klebanoff SJ et al: Morphologic correlates of glomerula oxidant injury induced by the myeloperoxidase-hydrogenperoxide -halide system of the neutrophil. Lad Invest 58 : 294-301, 1988.

20) Matheson NR, Wong PS, Travis J: Isolation and properties of human neutrophil myeloperoxidase: Biochem $20: 325-330,1981$.

21) Tomoda $K$, Maeda $N$, Kumazawa $T$ : An anionic charge barrier in the guinea pig cochlea. Arch Otorhinolaryngol 245 : 307-310, 1988.

稿を終えるにあたり，ご指導並びにご校閲を賜りました 八木聰明教授に深甚なる謝意を捧げます、また，本研究にあ たりご助言を頂いた Ruby Pawankar 先生に感謝いたしま す.

本論文の要旨は第 3 回日本耳科学会総会 (名古屋) で口演 した.

（1994年1月27日受稿 1994年 4 月 7 日受理）

別刷請求先 $\mathbf{1} 113$ 東京都文京区干駄未1-1-5

日本医科大学耳鼻咽喉科学教室 木下俊之 